\title{
Meningkatkan Psikomotorik Anak Berbasis Animasi Huruf Hijaiyah Dengan Metode Follow The Line
}

\author{
Sriyadi $^{1}$, Haryanto $^{2}$ \\ ${ }^{1}$ Universitas Bina Sarana Informatika \\ e-mail: sriyadi.sry@bsi.ac.id \\ ${ }^{2}$ Universitas Bina Sarana Informatika \\ e-mail: haryanto.hyt@bsi.ac.id
}

\begin{abstract}
Cara Sitasi: Sriyadi, \& Haryanto. (2019, Maret). Meningkatkan Psikomotorik Anak Berbasis Animasi Huruf Hijaiyah Dengan Metode Follow The Line. (S. Dalis, Ed.) Paradigma - Jurnal Komputer dan Informatika, 21(1), 127-132. doi:10.31294/p.v21i1.5301
\end{abstract}

\begin{abstract}
Learn to recognize and read hijaiyah letters which are the basis for reading and studying the Holy Qur'an from an early age. The Al-Qur'an learning method is widely used more in the introduction of hijaiyah letters by reading. So that children find it difficult when asked to write hijaiyah letters. Follow the line method is a way of learning that is done by combining learning activities and psychomotor movements of children. This simple method is done by thickening the hijaiyah letters that have been printed faintly into bold letters. In the process of thickening the letters, it will certainly train children to be patient and more thorough. By writing, the child also reads the letter at the same time. Which at the same time will train the movement of the child's limbs such as hands, eyes and other body parts will be more active again. Thus, this will further improve children's psychomotor abilities. The animation that is used will also be more interesting for children to learn the Qur'an.
\end{abstract}

Keywords: Hijaiyah Letter, Follow the Line Method, Psychomotor

\section{PENDAHULUAN}

Belajar Alqur'an untuk anak-anak terkadang menjadi kendala karena metodenya yang kurang menarik. Menurut (Husaini, 2013) santri di Taman Pendidikan Al-Qur'an (TPA) An-Nur Daleman Selama ini masih menggunakan buku iqro' sebagai media belajar huruf hijaiyah. Cara ini termasuk kurang disukai para santri.

Terlebih di era digital seperti sekarang ini dimana anak lebih tertarik dengan hal-hal yang berhubungan dengan tekhnologi seperti bermain game online ataupun menggunakan smartphone yang justru membuat anak-anak jarang melakukan aktifitas gerak pada anggota tubuh seperti tangan, mata dan lainnya. Yang dampaknya akan berpengaruh pada psikomotorik anak tersebut. Metode belajar Alqur'an untuk anak-anak di masa sekarang ini menawarkan bermacam cara belajar yang unik, kreatif dan inovatif.

Beberapa alternatif media belajar adalah lewat internet, buku atau media lain seperti CD interaktif. Media-media ini mendatangkan beberapa keuntungan dalam prakteknya seperti tidak terikat waktu, kapan saja dan di mana saja.

Pembelajaran yang interaktif akan memberikan dampak yang positif dalam proses pembelajaran.
Multimedia seringkali dikaitkan dengan computer based learning ini karena di dalam multimedia banyak digunakan perangkat komputer yang mampu menampilkan media yang beragam, seperti teks, gambar, suara, animasi, video, dan lain sebagainya. Oleh karena itu penyajian media pembelajaran yang beragam dalam suatu waktu disebut juga dengan multimedia pembelajaran. (Ramansyah, 2016)

Menurut Ahmad munir dan Sudarsono dalam (Srijatun, 2017) Jika seseorang mempunyai keinginan yang kuat untuk bisa membaca al-Qur'an dengan sebaik-baiknya, maka perlu penguasaan huruf, harakat, kalimat serta ayat-ayat yang disebut : muraah al huruf wa al harakat dan muraah al kalimah wa al ayah

Proses pembelajaran khususnya kepada anak-anak juga harus memperhatikan banyak hal terkait aktifitas si anak. Menurut Brown dalam (Nurwati, 2014) bahwa Pembelajaran bersinonim dengan pengalaman belajar aktivitas belajar, proses belajar, dan kegiatan belajar. Ini sejalan dengan pendapat Piaget bahwa pembelajaran adalah proses perkembangan yang melibatkan perubahan, pemunculan diri, dan konstruksi, yang masingmasing dibangun di atas pengalaman-pengalaman pembelajaran sebelumnya

Ranah psikomotor sangat berhubungan dengan hasil belajar yang pencapaiannya melalui keterampilan 
manipulasi yang melibatkan otot dan kekuatan fisik. Mata pelajaran yang berkaitan dengan psikomotor adalah mata pelajaran yang lebih beorientasi pada gerakan dan menekankan pada reaksi-reaksi fisik dan keterampilan tangan. Keterampilan itu sendiri menunjukkan tingkat keahlian seseorang dalam suatu tugas atau sekumpulan tugas tertentu (Nurwati, 2014). Salah satu metode pembelajaran yang menggabungkan antara belajar Al-Qur'an dan aktifitas psikomotor anak adalah metode Follow the line yaitu dengan cara menulis Al Quran dengan cara menebalkan garis atau titik-titik pada huruf atau bacaan Al-Qur'an. (Irawan, 2013)

\section{METODOLOGI PENELITIAN}

Metode pengumpulan data yang penulis gunakan dalam pembuatan skripsi ini adalah sebagai berikut:

A. Observasi

Penulis melakukan pencatatan, pengumpulan data serta melakukan pengamatan dengan langsung TPA untuk mengamati proses belajar mengajar.

B. Wawancara

Metode ini dilakukan dengan tanya jawab dengan guru dan kepala sekolah TPA

C. Studi Pustaka

Dengan metode ini dapat membantu penulisan dalam hal pembuatan skripsi yang ditunjang dengan beberapa literatur yang berhubungan dengan mempelajari buku-buku, jurnal, dan bahan pustaka lainnya.

\section{HASIL DAN PEMBAHASAN}

Pada pembuatan aplikasi ini bersifat pembelajaran, dibuat tidak terlalu berlebihan, dan dibuat semenarik mungkin sehingga mampu menyesuaikan dari fungsi dari multimedia ini. Pada beberapa halaman dan tombolnya diberikan suara, sehingga menambah efek menarik dari aplikasi ini. Aplikasi ini juga mudah digunakan (user friendly), tombol (button) penghubung antar Scan dengan Scan yang lainnya mudah diketahui, sehingga tidak mempersulit pengguna untuk menggunakannya. Tampilan user interface dari aplikasi ini antara lain :

\section{Tampilan Menu Opening}

Tampilan Menu Opening ini berisi tentang judul program animasi yang sedang dimainkan, 1 tombol mulai untuk memulai aplikasi tersebut.

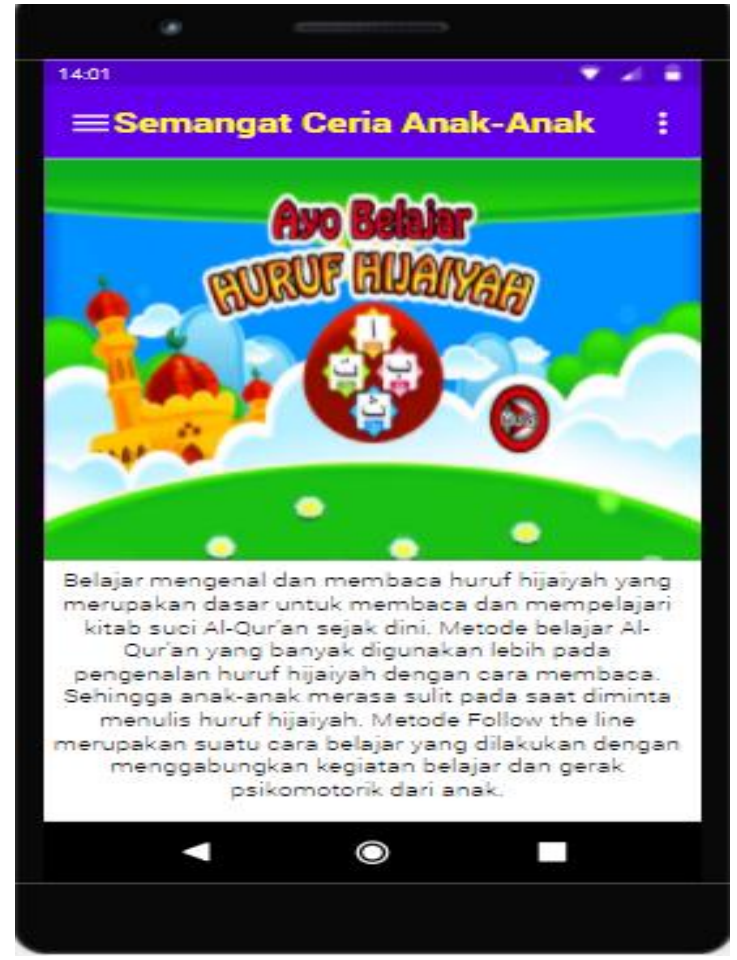

Gambar III.1. Tampilan Opening

\section{Tampilan Menu Utama}

Tampilan menu utama ini berisi 4 menu dan 1 tombol navigasi untuk keluar, diantaranyaberlajar 1 berisi tentang pengertian dan huruf hijaiyah, belajar 2 berisi huruf hijiayah dengan di beri fatha, latihan soal berisi soal mencocokan gambar dan mencocokan suara huruf hijaiyah dan gamesberisi permainan puzzle dengan gambar huruf hijaiyah.

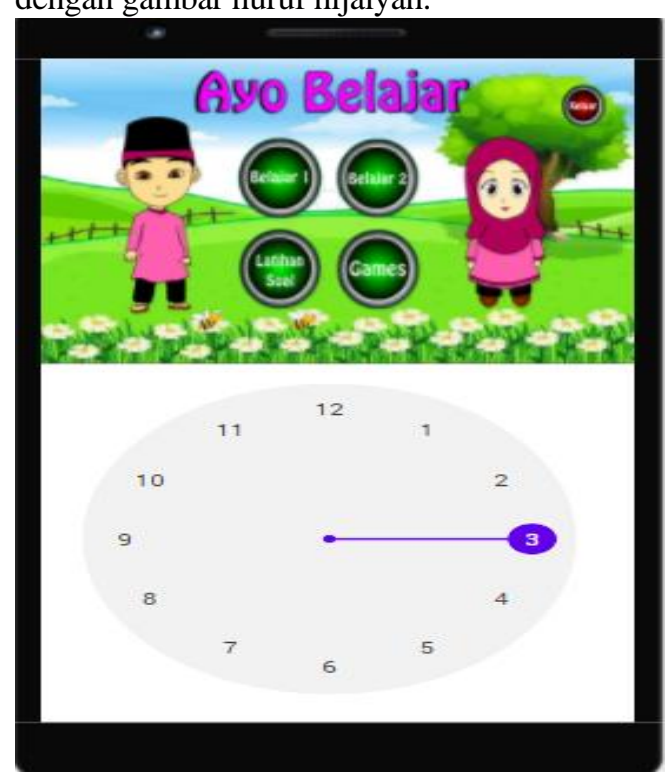

Gambar III.2. Menu Utama 
3. Tampilan Belajar 1

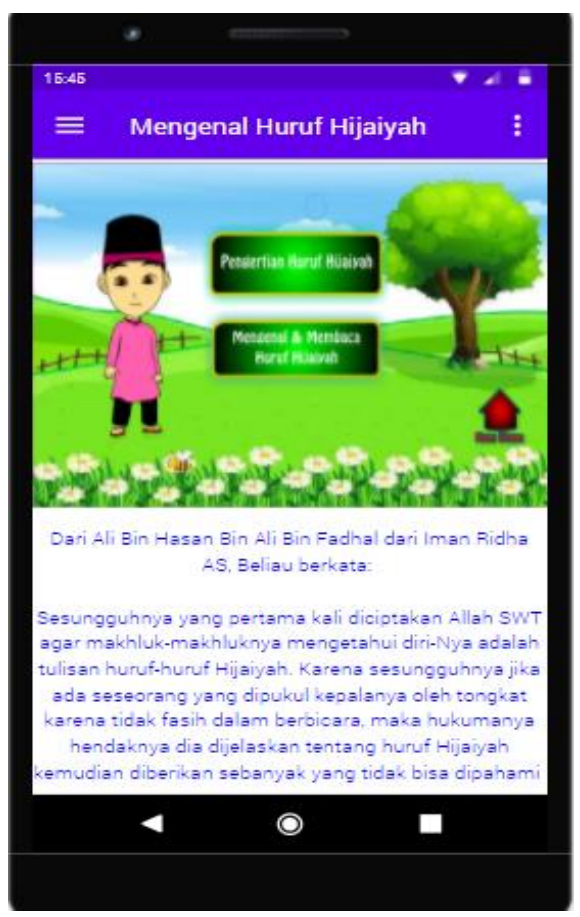

Gambar III.3. Menu Huruf Hijaiyah

4. Tampilan Menu Mengenal dan Membaca Huruf Hijaiyah 1

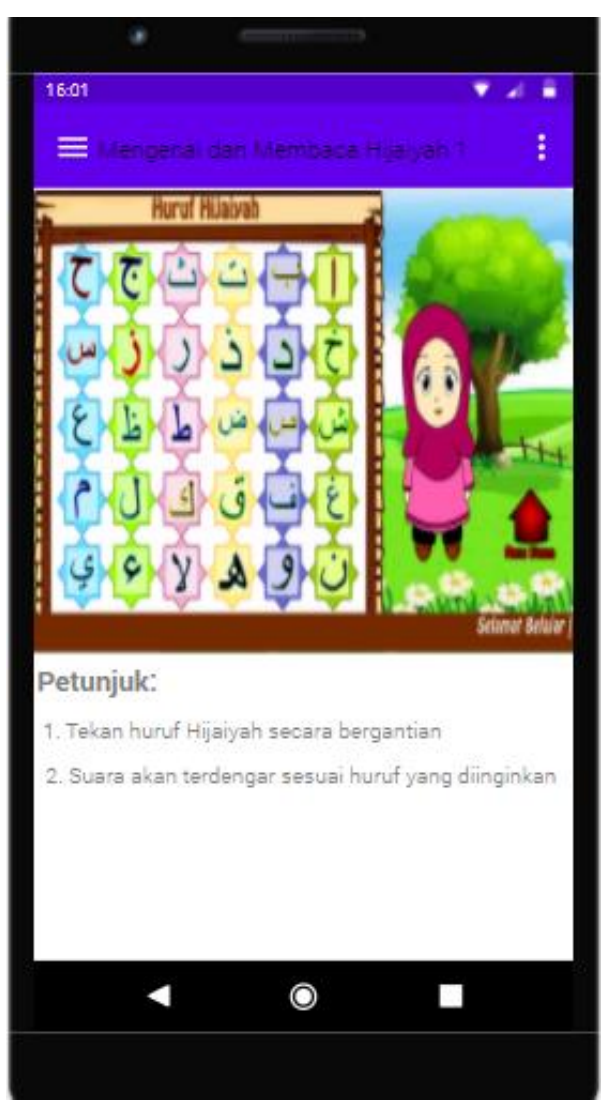

Gambar III.4. Menu Mengenal dan Membaca Huruf Hijaiyah
5. Tampilan Menu Mengenal dan Membaca Huruf Hijaiyah 2

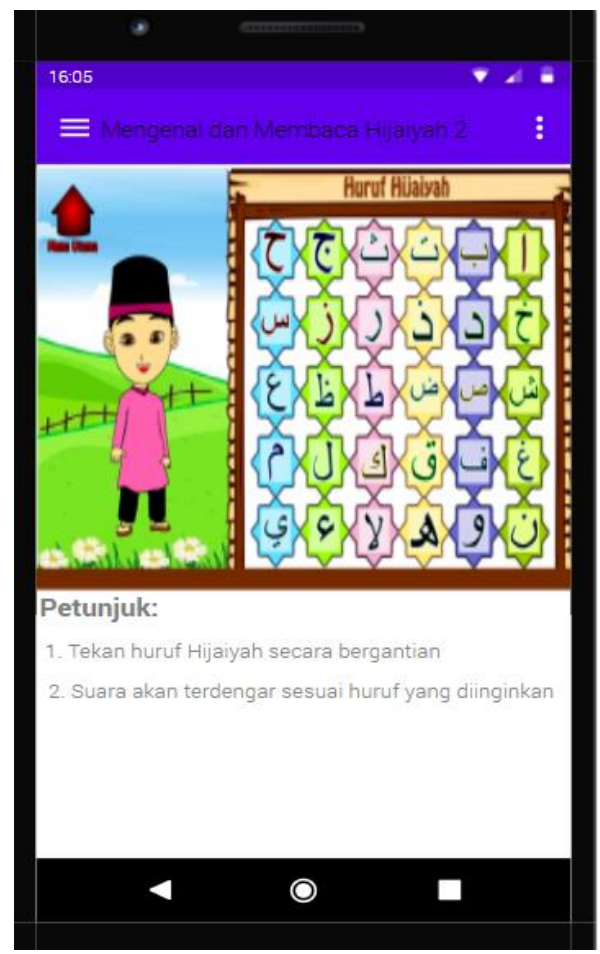

Gambar III.5. Menu Mengenal dan Membaca Huruf Hijaiyah

6. Tampilan Menu Menulis Huruf Alif Metode Folow The Line

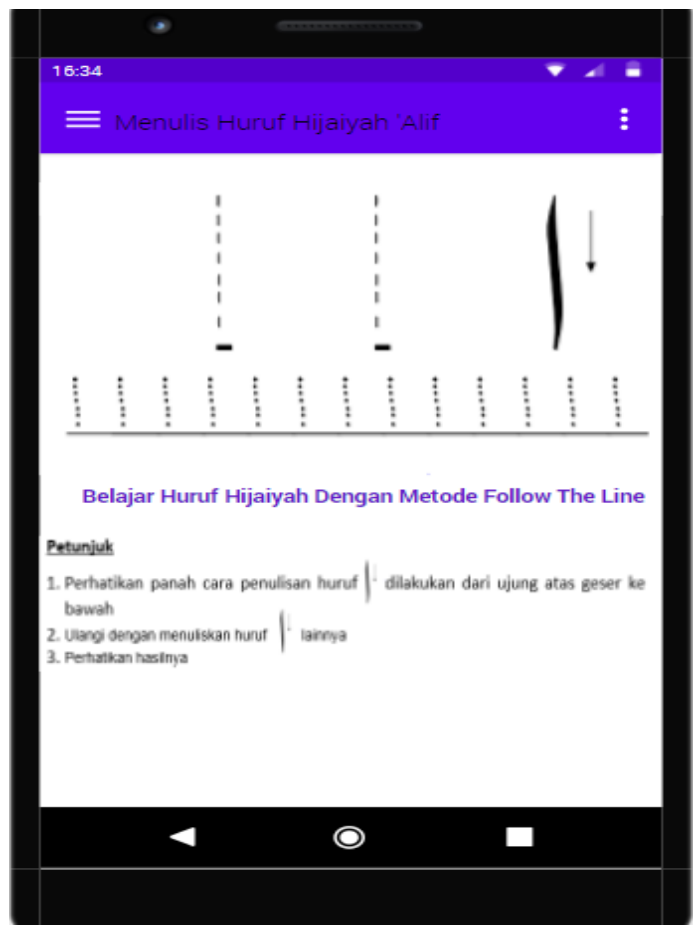

Gambar III.6. Menu Menulis Huruf Alif Follow The Line 
7. Tampilan Menu Menulis Huruf Baa Metode Folow The Line

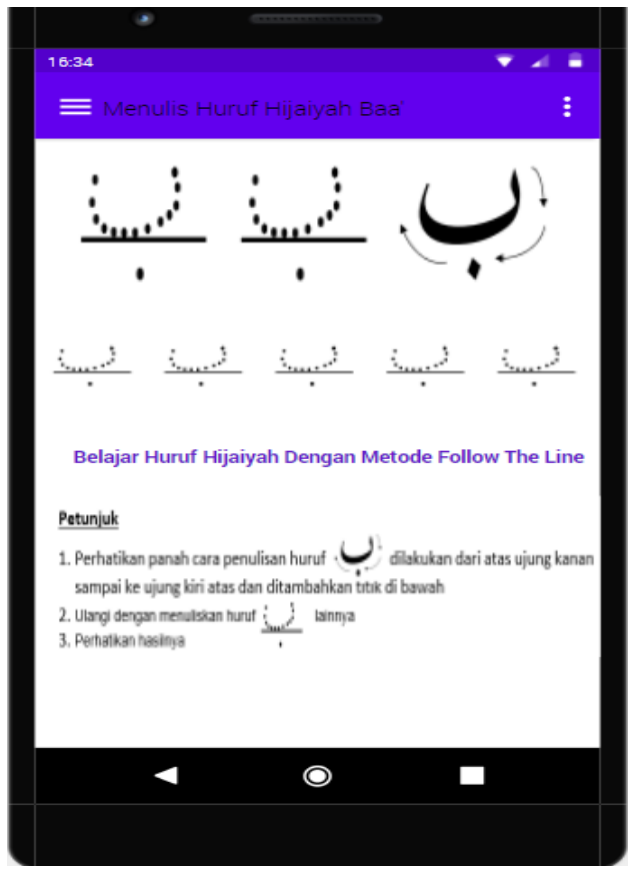

Gambar III.7. Menu Menulis Huruf Baa Follow The Line

8. Tampilan Menu Menulis Huruf Taa Metode Folow The Line

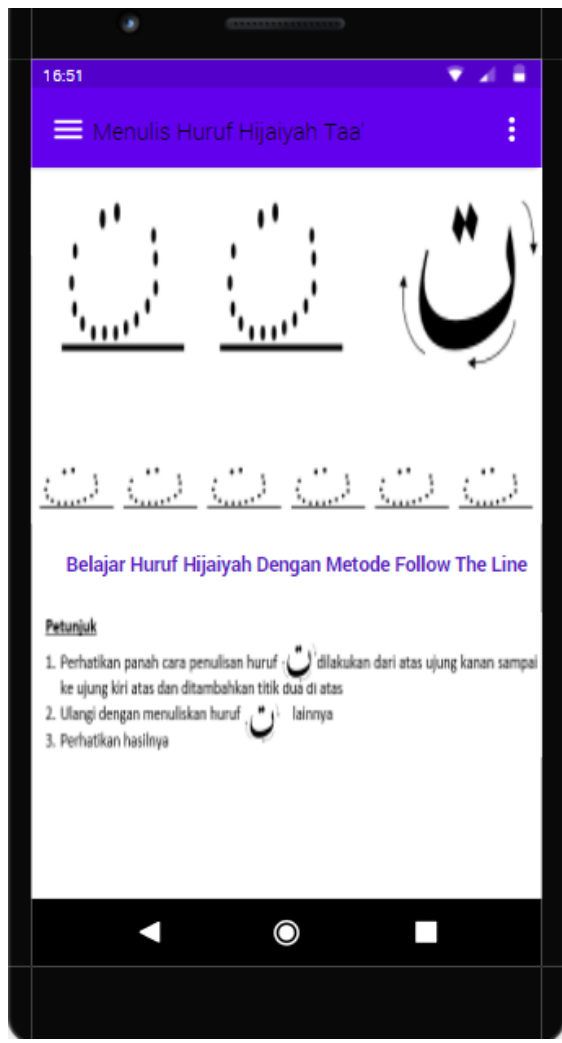

Gambar III.8. Menu Menulis Huruf Baa Follow The Line
9. Tampilan Menu Games

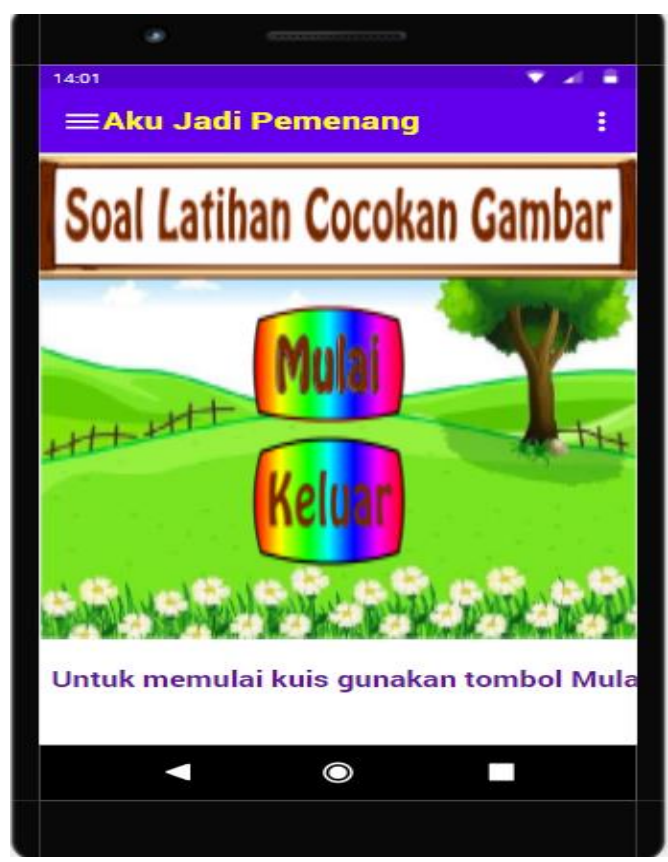

Gambar III.9. Menu Latihan Soal

10. Tampilan Menu Games

Tampilan games ini berisi permainan puzzle bergambar huruf hijaiyah.

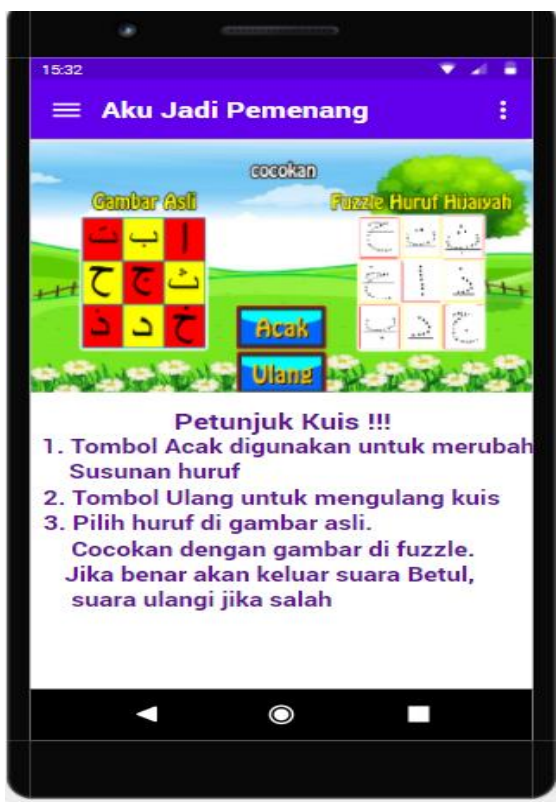

Gambar III.10. Menu Games 
Bagan alir dari tampilan latihan soal sebagai berikut

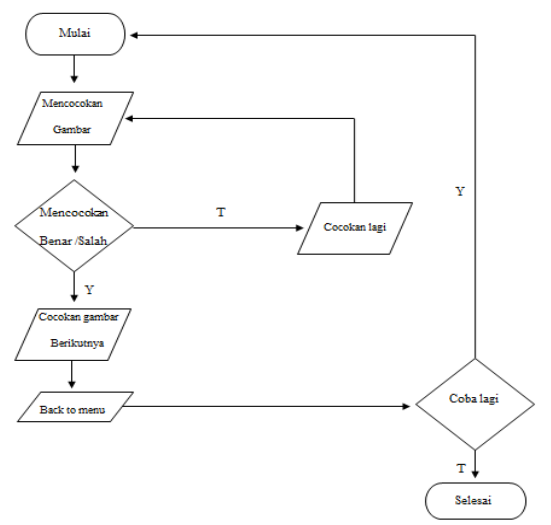

Gambar III.18.

Bagan Alir From Latihan Soal

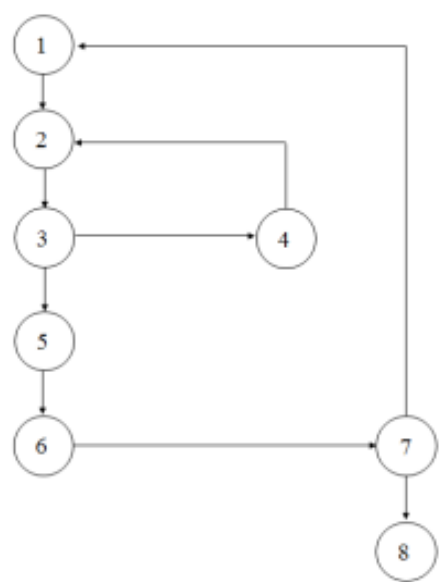

Gambar III.11.

Bagan Alir From Latihan Soal

Kompleksitas siklomatis (pengukuran kuantitatif terhadap kompleksitas logis suatu program) dari grafis alir dapat diperoleh dengan perhitungan : Dimana :

$$
\mathrm{V}(\mathrm{G})=\mathrm{E}-\mathrm{N}+2
$$

$\mathrm{E}=$ jumlah edge grafik alir yang ditandakan dengan gambar panah

$\mathrm{N}=$ jumlah simpul grafik alir yang ditandakan dengan gambar lingkaran sehingga kompleksitas siklomatisnya. $\mathrm{V}(\mathrm{G})=9-8+2=3$

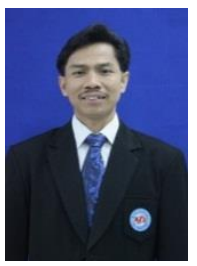

Sriyadi, M.Kom. Tahun 2005 lulus pendidikan Program Strata Satu (S1) Program Studi Sistem Informasi Sekolah Tinggi Manajemen Informatika dan Komputer (STMIK) Nusa Mandiri Jakarta. Tahun 2011 lulus Program Strata Dua (S2) Pascasarjana STMIK Nusa Mandiri dengan konsentrasi bidang

\section{$1-2-3-5-6-7-8$}

\section{$1-2-3-4-2-3-5-6-7-8$}

1-2-3-5-6-7-1-2-3-5-6-7-8

Kesimpulan bahwa ketentuan tersebut dari segi kelayakan software. System ini telah memenuhi syarat.

\section{KESIMPULAN}

Metode pembelajaran Al-Qur'an Follow The Line yang dalam penerapannya mengajak anak-anak untuk menulis dengan cara mempertebal garis atau titik-titik pola huruf hijaiyah maupun bacaan AlQur'an, secara otomatis akan meningkatkan gerakan dan menekankan pada reaksi-reaksi fisik dan keterampilan tangan. Sehingga kemampuan psikomotorik anak akan lebih meningkat.

\section{REFERENSI}

Husaini, F. (2013). Pembuatan Media Edukasi Ayo Bermain Huruf Hijaiyah Pada Tpa An-Nur Daleman, 2(1), 68-74.

Irawan, L. (2013). No Title. Retrieved from https://www.antaranews.com/berita/391847/fo llow-the-line-metode-mudah-belajar-al-quran

Nurwati, A. (2014). Penilaian Ranah Psikomotorik Siswa Dalam Pelajaran Bahasa A. Pendahuluan Penilaian merupakan suatu kegiatan yang tidak mungkin dipisahkan dari kegiatan pendidikan dan pengajaran secara umum . Semua kegiatan pendidikan yang dilakukan harus selalu diikuti, 9(2), 385-400.

Ramansyah, W. (2016). Pengembangan Multimedia Pembelajaran Interaktif Dengan Tema Pengenalan Huruf Hijaiyah Untuk Peserta Didik Sekolah Dasar, 3(1), 28-37.

Srijatun. (2017). Implementasi Pembelajaran Baca Tulis Al- Qur' an Dengan Metode Iqro Pada Anak Usia Dini Di RA Perwanida Slawi Kabupaten Tegal . Srijatun UIN Walisongo Semarang Pendahuluan Usia dini merupakan periode awal yang paling penting dan mendasar dalam sepanjang. Nadwa | IAIN Walisongo, 11, 25-42.

Manajemen Information System (MIS). Aktifitas sebagai dosen Universitas Bina Sarana Informatika. Karya peneltian: Sistem Informasi E-Kepegawaian Pada PT. Mannapratama Santosa Jakarta terbit pada jurnal Information System For Educators And Professionals, Solusi Cerdas Menyusun Laporan Pertanggungjawaban Koperasi Dengan Penerapan EKoperasi diterbitkan pada jurnal Ilmu Ekonomi dan Pembangunan, Sistem Informasi Penerimaan 
Peserta Didik Baru (PPDB) Online Pada Madrasah Aliyah Negeri 17 Jakarta pada Seminar Nasional Inovasi dan Tren (SNIT) 2018, Pemakalah pada

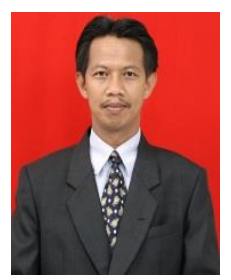

Haryanto, M.Kom. Tahun 2002 lulus pendidikan Program Strata Satu (S1) Program Studi Manajemen Informatika STMIK Kuwera Jakarta. Tahun 2014 lulus program Strata Dua (S2) Pascasarjana STMIK Nusamandiri konsentrasi Sistem Informasi Manajemen. Aktifitas sebagai dosen Universitas Bina Sarana Informatika. Karya penelitian $3 . \quad$ Kajian Implementasi Pembelajaran Berbasis E-learning dengan Pendekatan Unified Theory of Acceptance and Use of Technology (UTAUT) (Studi Kasus pada SMP Al-Amanah, Kota Tangerang Selatan) diterbitkan di jurnal Khatulistiwa Informatika
Forum International Conference On Islamic s and Philantropy 